\title{
Observed changes in SAT and GDD and the climatological suitability of the Poland-Germany-Czech Republic transboundary region for wine grapes cultivation
}

\author{
Maciej Kryza • Mariusz Szymanowski • Marek Błaś • \\ Krzysztof Migala $\cdot$ Malgorzata Werner $\cdot$ Mieczysław Sobik
}

Received: 31 March 2014 / Accepted: 27 September 2014 /Published online: 10 October 2014

(C) The Author(s) 2014. This article is published with open access at Springerlink.com

\begin{abstract}
In this study, we show how the climatological suitability of wine grapes cultivation of the transboundary region of Poland, Germany and the Czech Republic has changed over the 1971-2010 period. Strong, positive and statistically significant trend in sum of active temperatures (SAT) and growing degree days (GDD) is observed. The trend is more pronounced in the lowland areas of the study region. The total acreage suitable for more demanding, in terms of SAT and GDD, varieties of wine grapes is increasing, while the opposite trend is observed for less demanding classes. The observed trends reduce the risk for wine grapes cultivation in terms of accumulative SAT and GDD indices. This shows that the transboundary area of Poland, Germany and Czech Republic shifts towards the climate more suitable for viticulture.
\end{abstract}

\section{Introduction}

During the last century, Europe was strongly affected by the increase in air temperatures (measured at $2 \mathrm{~m}$ above the surface), up to $0.9^{\circ} \mathrm{C}$ in annual mean in the $1901-2005$ period (Kjellstrom 2004). After a very variable period of 1935-1980, a strong positive trend is observed for air temperature, which was not previously observed since meteorological records in 1750 began (Jones and Moberg 2003). The observed climate changes have large impact on agricultural production in terms of various crops (Lobell et al. 2008; Lobell et al. 2007; Olesen and Bindi 2002). This includes vine phenology and grapes composition, advanced harvest times, increased grape sugar

M. Kryza $(\bowtie) \cdot$ M. Szymanowski • M. Błaś • K. Migała •

M. Werner $\cdot$ M. Sobik

Institute of Geography and Regional Development, Wrocław

University, ul. Kosiby 8, 51-621 Wrocław, Poland

e-mail: maciej.kryza@uni.wroc.pl concentrations and high alcohol level in wine (de Orduna 2010). This is potentially a threat to the current, traditional wine regions but also makes other areas, e.g. located in north and central Europe, available for wine grapes cultivation. According to Jones et al. (2005), the regions of high-quality grapes production are at the margins of their climatic limits. For the other areas, e.g. in Central Europe, the observed changes in climate could push some regions into more optimal climate regimes for the production of wine grapes (Jones et al. 2005). Several papers reported that earlier maturity was observed in typical regions of wine production, e.g. in Italy (Webb et al. 2012), France (Duchene et al. 2010) and Australia (Webb et al. 2011), and this was linked with the climate changes observed in recent years.

Adverse effects of climate change include, among others, threats to traditional, regional wine grapes varieties (Bock et al. 2011), but the majority of the Western and Central European wine-producing regions have benefited from the observed trends in climate. The observed warmer season, e.g. in Lower Franconia, Germany (Bock et al. 2011), results in greater ripening potential of wine grapes but also has an impact on higher sugar content, and this alters the wine typicity.

The changes in climate over the recent decades are also responsible for the increase of the area of land potentially suitable for grapevine cultivation. The regions of premium wine quality production, e.g. these in Europe, shift towards higher elevations and increase in their total area (Moriondo et al. 2011). The spatial shifts in premium wine productions are reported also from the USA (White et al. 2006).

The focus of this study is on the transboundary area of western Poland (Dolnośląskie and Lubuskie voivodships), eastern Germany (Saxony and Brandenburg states) and northern part of the Czech Republic. Apart from the mountainous part of the Czech Republic, the regions of SW Poland and Saxony were traditional areas of viticulture and wine making. 

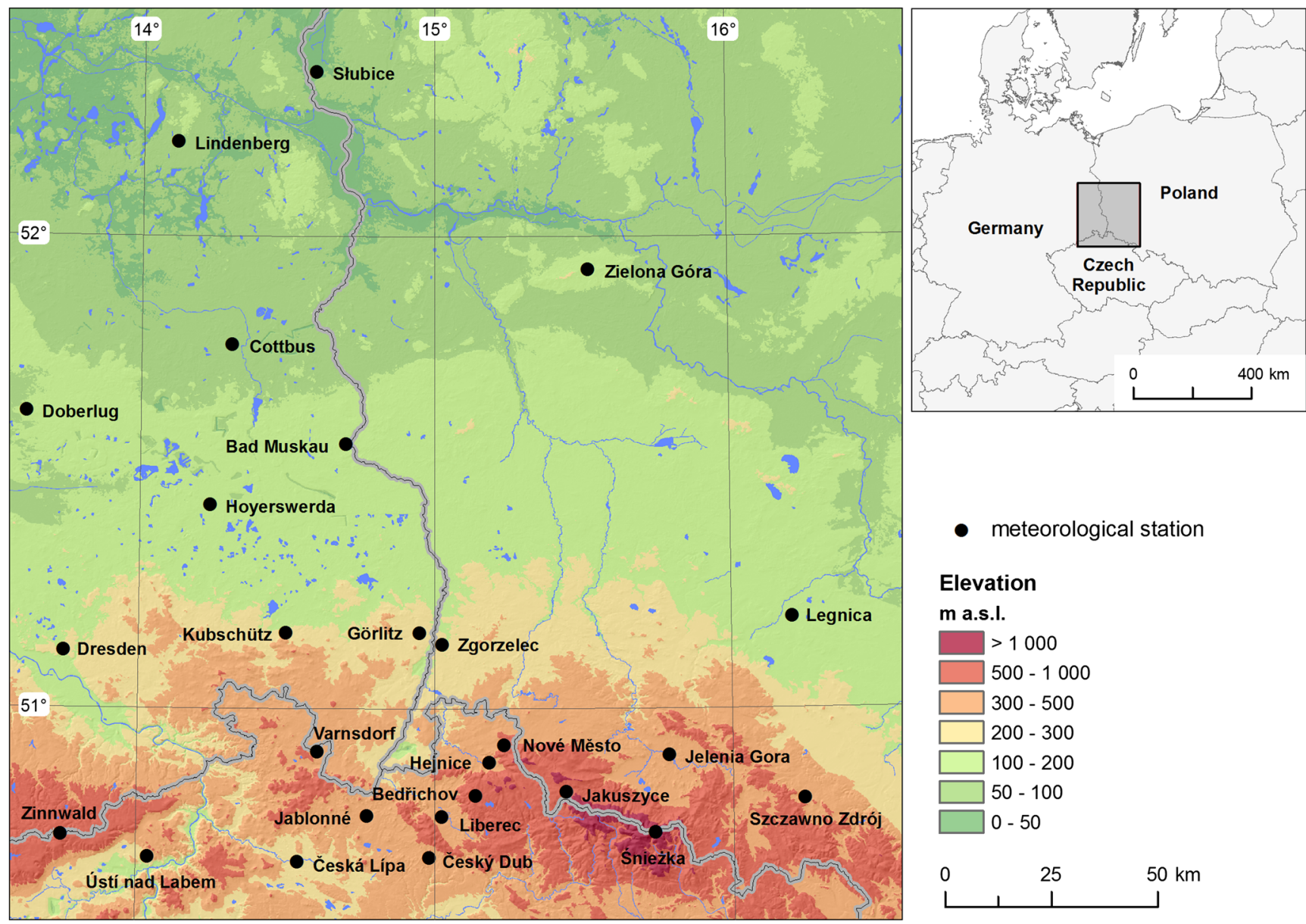

- meteorological station

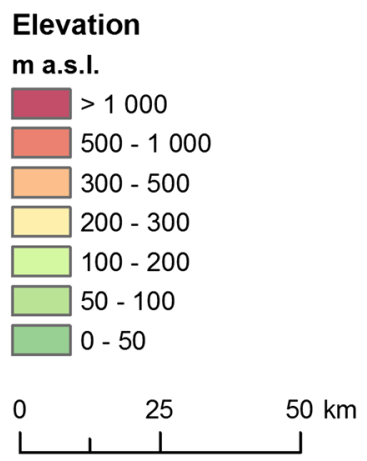

Fig. 1 Study area and location of the meteorological stations used in this work

At the beginning of the 20th century, total area of vineyards in SW Poland was nearly 1,500 ha. Afterwards, mainly because of various social and economical reasons, there was a strong decrease in wine production, with the last mass-producing vineyards closed in 1970s. In recent years, however, there has been an increase in production of wine and cultivation of wine grapes in this area. This was inspired, e.g. in Poland, by changes in law and economic conditions after the access to the European Union. This is an example of shifting the regions of wine grapes cultivation towards north, as pointed by Jones et al. (2005).

There are three major climatological factors affecting wine grape production (White et al. 2006): adequate heat accumulation, low risk of severe frost damage and the absence of extreme heat. Because of the transboundary area of this study, it was not possible to derive sufficient and homogeneous climatological characteristics to address the extremes in a spatial manner: frost damage and heat stress.

The main aim of this paper is to present and discuss the spatial distribution of sum of active temperatures (SAT) and growing degree days (GDD) in the context of climatological suitability of the study area for wine grape cultivation. The trends in annual values of SAT and GDD are provided as high- resolution spatial information and presented in maps for the period of 1971-2010. Finally, the recent trends in changing the total area climatologically suitable for wine grape cultivation are presented, as an important scientific message that may be useful for climate change adaptation strategies.

\section{Data and methods}

\subsection{Study area}

The focus of this study is on the transboundary region of Poland, Germany and the Czech Republic (Fig. 1). The terrain changes from lowlands in the north, with altitudes at ca. $50 \mathrm{~m}$ above sea level (a.s.1.), through highlands and mountains in the south, with elevations up to 1,602 m a.s.l. (Mt. Śnieżka in the Karkonosze Mountains). The dominating categories of land use in this region (total area of $45,365 \mathrm{~km}^{2}$ ) are agriculture $(41.8 \%)$ and forest $(41.7 \%)$, according to the Corine Land Cover 2006 database.

The region is characterized by transitional climate in the west wind zone, with maritime influences decreasing from west to east. The strong continental influence is reflected in a larger 
Table 1 Average sum of active temperatures (SAT) $\left({ }^{\circ} \mathrm{C}\right)$ and ripening ability of groups of grape varieties

\begin{tabular}{ll}
\hline SAT & Varieties \\
\hline $2,000-2,200$ & Very early ripening \\
$2,200-2,500$ & Early ripening \\
$2,500-2,700$ & Moderately early ripening \\
$2,700-2,900$ & Late ripening \\
$>2,900$ & Very late ripening \\
\hline
\end{tabular}

From Myśliwiec 2003

annual amplitude of the mean monthly air temperature and lower mean annual precipitation amount in Legnica in the east ( $18.5^{\circ} \mathrm{C}$ and $515 \mathrm{~mm}$, respectively), as compared to Dresden in the west of the region $\left(18.2{ }^{\circ} \mathrm{C}\right.$ and $663 \mathrm{~mm}$, respectively).

Regional climatic differences are decisively influenced by the mountains in the south of the study area; namely, there is a large difference in the average air temperature between the lowlands (Lindenberg $9.2{ }^{\circ} \mathrm{C}$ ) and mountains (Śnieżka $0.8^{\circ} \mathrm{C}$ ). With S-SW flow direction, the "foehn effects" (mild wind) occur at the foreground (the lee side) of the mountains, leading to $0.5-1.0{ }^{\circ} \mathrm{C}$ increase in annual average air temperatures, compared to the windward side of the mountains. On the other hand, occasionally observed is the regional "Bohemian wind"- a gusty fall cold wind during the winter months. Additionally, small-scale climate variability (pool of cold air, temperature inversions) is observed due to terrain complexity.

\subsection{Meteorological data and agroclimatological indices}

Daily 2-m air temperature measurements were available for 26 meteorological stations in the study area for the period of 1971-2010 (Fig. 1). This period was important for a warming course on a global scale (WMO 2013). For the 1950s and 1960s, a characteristic phase of roughly no increase or even decrease in air temperature was apparent. Since the late 1970s, an accelerated increase in the mean temperature was observed (Trenberth et al. 2007). Six out of ten maximum values of mean annual temperature, recorded in the period 1951-2000 in Poland, occurred during the last decade of the 20th century (Kożuchowski and Degirmendžić 2005). Furthermore, the decadal rate of increase in the global temperature increased between 1971 and 2010. The global temperature increased at an average estimated rate of $0.17^{\circ} \mathrm{C}$ per decade during that period, compared with $0.062{ }^{\circ} \mathrm{C}$ per decade for the entire 1880-2010 period. The average 2001-2010 decadal air temperature was $0.21^{\circ} \mathrm{C}$ warmer than $1991-2000$, which in turn was $+0.14^{\circ} \mathrm{C}$ warmer than $1981-1990$ (WMO 2013).

The location of the measuring sites is shown in Fig. 1. The data were tested for quality and the gaps filled using the data from the nearest station. All the stations used in the study had the complete series of daily observations for the entire study period.

Two agroclimatological indices were calculated from the daily 2-m air temperatures for each station and each year of the study period. The indices selected were as follows:

- Sum of active temperatures (SAT)

- Growing degree days (GDD)

SAT is considered to be one of the most important thermal parameters in agroclimatology in general. It is estimated that the SAT in a vineyard should be equal or higher than $2,000{ }^{\circ} \mathrm{C}$ (Myśliwiec 2003). SAT is the sum of mean daily temperatures equal or higher than $10{ }^{\circ} \mathrm{C}$ (Lisek 2008) from the period 1 April-31 October (Jones and Davis 2000). It is calculated as follows:

$\mathrm{SAT}=\sum_{01.04}^{31.10} T_{\mathrm{d}} \quad$ for $\quad T_{\mathrm{d}} \geq 10^{\circ} C$

where $T_{\mathrm{d}}$ is the daily mean air temperature. SAT can be classified to describe the ripening ability for different types of grapes, and the classification proposed by (Myśliwiec 2003) was used in this study (Table 1). Each grape variety has its own minimum average SAT value required during the vegetation period.

Table 2 Grape-growing regions based on GDD

\begin{tabular}{|c|c|c|c|c|}
\hline Region & $\operatorname{GDD}\left({ }^{\circ} \mathrm{C}\right)$ & Suggested varieties & Type & Similar region to \\
\hline I & $\leq 1,371$ & Early-ripening varieties to achieve high quality & Very cool & $\begin{array}{l}\text { The coolest European districts such as } \\
\text { Champagne in France and the Rhine } \\
\text { in Germany }\end{array}$ \\
\hline II & $1,372-1,648$ & Early and mid-season table wine varieties & Cool & Bordeaux in France \\
\hline III & $1,649-1,927$ & High yield of standard to good quality wines & Warm & The Rhone in France or Tuscany in Italy \\
\hline IV & $1,928-2,204$ & High yield, but wine quality is only acceptable & Hot & The San Joaquin Valley \\
\hline V & $\geq 2,204$ & $\begin{array}{l}\text { High production of late-season wine and table } \\
\text { varieties for bulk production }\end{array}$ & Very hot & $\begin{array}{l}\text { Only table grapes are usually grown } \\
\text { commercially in this region }\end{array}$ \\
\hline
\end{tabular}

From Amerine and Winkler 1944 
Heat unit expressed in growing degree days (GDD) describes the heat energy received by the crop maturity over a given time period to progress in development or growth processes (Yang et al. 1995). The GDD follows the equation:

$\mathrm{GDD}=\sum_{01.04}^{31.10} T_{\mathrm{d}}-10^{\circ} \mathrm{C}$

Detailed reviews of the concept of GDD were presented by Gilmore and Rogers (1958), Arnold (1960), Wang (1960), Pruess (1983), McMaster and Wilhelm (1997) and Bonhomme (2000). GDD is used to predict the vine's ability to mature as high-quality crop in the northern hemisphere Amerine and Winkler (1944). Therefore, suitability models must measure heat unit accumulation to ensure sufficient crop maturity. Amerine and Winkler (1944) divided the viticultural areas into five regions based on the GDD value (Table 2).

According to this general classification shown in Table 2, the entire study region is classified as very cool grape-growing region (region I). Therefore, in this study, the classification specific for the cool regions, like German Rhone area, is applied (Table 3).

Finally, as the SAT and GDD describe slightly different elements of climate, both indices are combined into one common classification (Szymanowski et al. 2010). There are four classes in this classification (Table 4).

\subsection{Spatial interpolation}

Agroclimatological indices were calculated for each meteorological site and for each year separately. This information was considered as an input for spatial interpolation. The indices were spatially interpolated using the geographically weighted regression kriging approach (GWRK; Szymanowski and Kryza 2012; Szymanowski et al. 2013). The GWRK approach was selected, as it was found to outperform other interpolation algorithms like multiple regression or kriging (Szymanowski et al. 2013; Szymanowski et al. 2012). The GWRK is a twostep procedure. First, the geographically weighted regression (GWR) model is determined to describe the relations between the modelled climatological variable and spatial predictor. Because of the limited number of stations available and

Table 3 GDD suitability classes for cool-climate growing regions

\begin{tabular}{lll}
\hline Class & GDD & Suitability \\
\hline 1 & $>1,389$ & Most suitable \\
2 & $1,165-1,389$ & Good suitability \\
3 & $945-1,164$ & Fair suitability \\
4 & $<945$ & Questionable suitability \\
\hline
\end{tabular}

Table 4 Wine-growing region classification based on SAT and GDD

\begin{tabular}{llll}
\hline Region & SAT and GDD & Profile \\
\hline 1 & $<2,500$ & $<945$ & $\begin{array}{c}\text { Not suitable and questionable } \\
\text { suitability for very early and } \\
\text { early ripening }\end{array}$ \\
2 & $2,500-2,900$ & $945-1,164$ & $\begin{array}{c}\text { Fair suitability for moderately } \\
\text { early and late ripening }\end{array}$ \\
3 & $>2,900$ & $945-1,164$ & $\begin{array}{c}\text { Fair suitability for very late } \\
\text { ripening } \\
\text { Good suitability for very late } \\
\text { ripening }\end{array}$ \\
\hline
\end{tabular}

relatively small area covered with the analysis, only elevation was considered as a spatial predictor. It must be emphasized that the elevation is not the only factor influencing the spatial pattern of air temperature. There are significant differences between the southern and northern slopes of the mountains for the same altitude that might exceed $1{ }^{\circ} \mathrm{C}$. However, with the measurements available for this study, which were gathered at regular meteorological network, the assessment of the role of slope and aspect was not possible. The other predictors were also tested, including coordinates and foehn index, but these were statistically insignificant. The exception was the $y$ coordinate, which was statistically significant, but strongly correlated with elevation and, therefore, removed from the group of predictors. GWR estimation of $z$ variable at location $s_{0}$ is calculated as follows:

$\widehat{z}\left(s_{0}\right)=\sum_{k=0}^{p} \widehat{\beta}_{k}\left(s_{0}\right) q_{k}\left(s_{0}\right)$

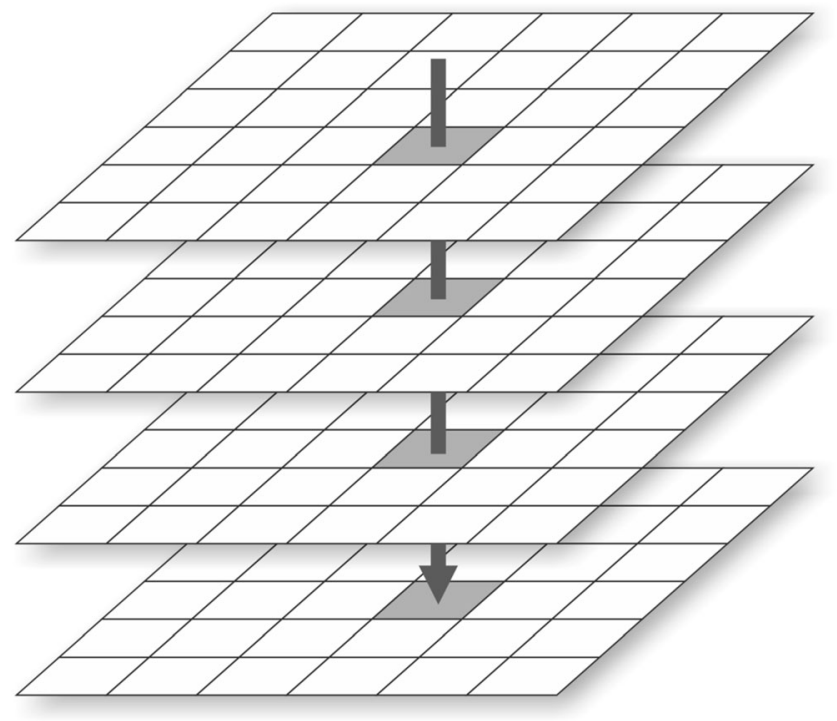

Fig. 2 Theoretical background of the local functions analysis. Only one cell on a given raster layer is involved in calculation, but several raster layers can be involved each time 
Fig. 3 Temporal variability of the SAT values observed at selected meteorological stations in the study area. Elevation of the stations (m a.s.1.): Cottbus 69, Görlitz 238, Jelenia Góra 342, Bedřichov 777 and Śnieżka 1602

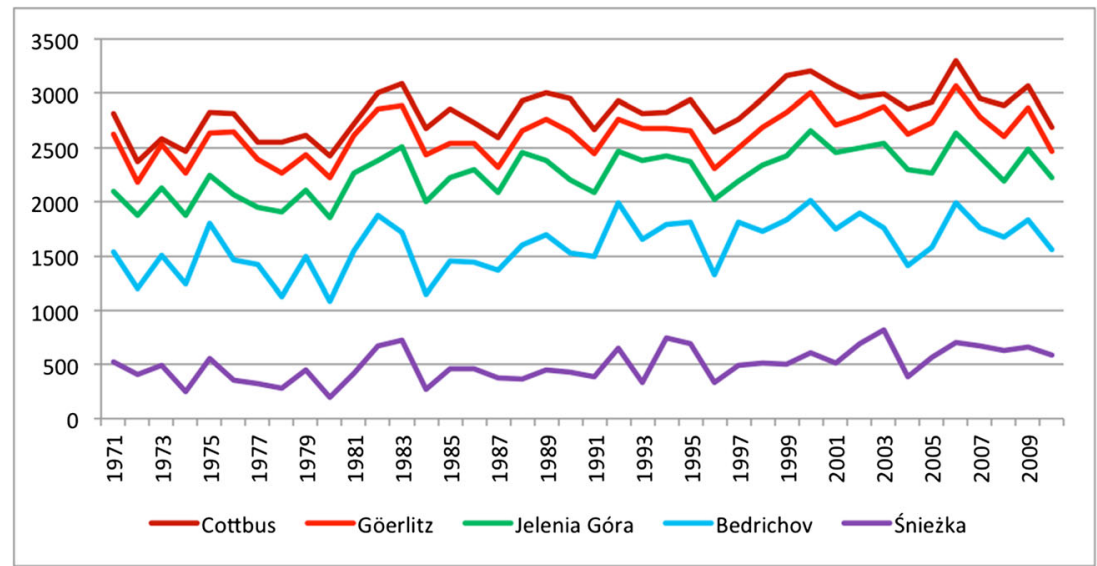

where $\widehat{\beta}_{k}\left(s_{0}\right)$ are the estimated deterministic model coefficients at location $s_{0}$, and $q_{k}\left(s_{0}\right)$ are the values of explanatory variables at location $s_{0}$.

The GWR model can be understood as a set of local regression fits in moving window, differing from other local regression models by applying a weighting scheme, using the distance-decay function of Gaussian type (kernels). This may be perceived as the implementation of the so-called the first law of geography, stressing similarities of closely located objects (Tobler 1970). Second, regression model residuals are spatially interpolated using ordinary kriging and added to the spatial prediction of the GWR model. The interpolation procedure was performed with R and GIS GRASS systems, using spgwr and gstat packages. Agroclimatological indices were interpolated onto the $1 \mathrm{~km} \times 1 \mathrm{~km}$ grid mesh. For each agroclimatological indicator, 40 maps were calculated, one for each year of the 1971-2010 period.

For each agroclimatological indicator, after the spatial interpolation described above, spatially continuous information on the indicator value is available for each grid cell covering the KLAPS project area (45,365 grid points). This information is available for each year of the study period. Therefore, for each grid point, it is possible to derive a time series of the given agroclimatological indicator.

\subsection{Spatial analysis}

With the series of 40 raster layers for SAT and GDD, it was possible to apply local functions for each raster grid cell to describe the climatological suitability for wine grapes growing of the study area. The main point of the analysis with the local functions is that each grid cell is treated individually. If there are several grid cells involved, they must be allocated to the same spatial location and different layers, as shown in Fig. 2. Actually, this type of analysis is fairly similar to the traditional climatological approach based on point measurements. However, here, we have "station data" (i.e. grid cells) regularly distributed and available every $1 \mathrm{~km}$ (spatial resolution applied in this work), and the final result forms gridded, spatially continuous information.

A very large number of local functions can be defined. Here, we calculated, for each grid cell, the following information:

- Spatial patterns of the average SAT and GDD values for the 1971-2010 period.

- Spatial patterns of the SAT and GDD for the coldest and the warmest year of the 1971-2010 period.

- Reclassified SAT and GDD values into classes suitable for wine grapes cultivation.

Table 5 Statistical summary of the SAT and GDD for the selected stations

\begin{tabular}{|c|c|c|c|c|c|c|c|c|}
\hline \multirow[t]{2}{*}{ Station } & \multicolumn{4}{|l|}{ SAT } & \multicolumn{4}{|l|}{ GDD } \\
\hline & Mean & Min & Max & $\mathrm{sd}$ & Mean & Min & Max & $\mathrm{sd}$ \\
\hline Cottbus & $2,829.1$ & $2,370.4$ & $3,297.2$ & 212.1 & $1,123.0$ & 869.3 & $1,388.6$ & 119.9 \\
\hline Görlitz & $2,613.0$ & $2,178.9$ & $3,063.3$ & 210.5 & 980.7 & 756.5 & $1,215.5$ & 117.3 \\
\hline Jelenia Góra & $2,256.8$ & $1,848.7$ & $2,655.8$ & 211.7 & 759.6 & 523.8 & 967.8 & 111.1 \\
\hline Bedřichov & $1,597.5$ & $1,080.2$ & $2,013.5$ & 241.1 & 489.9 & 278.2 & 688.0 & 105.9 \\
\hline Śnieżka & 498.6 & 195.1 & 817.1 & 152.3 & 111.0 & 36.0 & 222.1 & 44.9 \\
\hline
\end{tabular}

Mean arithmetic mean, Min minimum value, Max maximum value, $s d$ standard deviation for the 1971-2010 period 

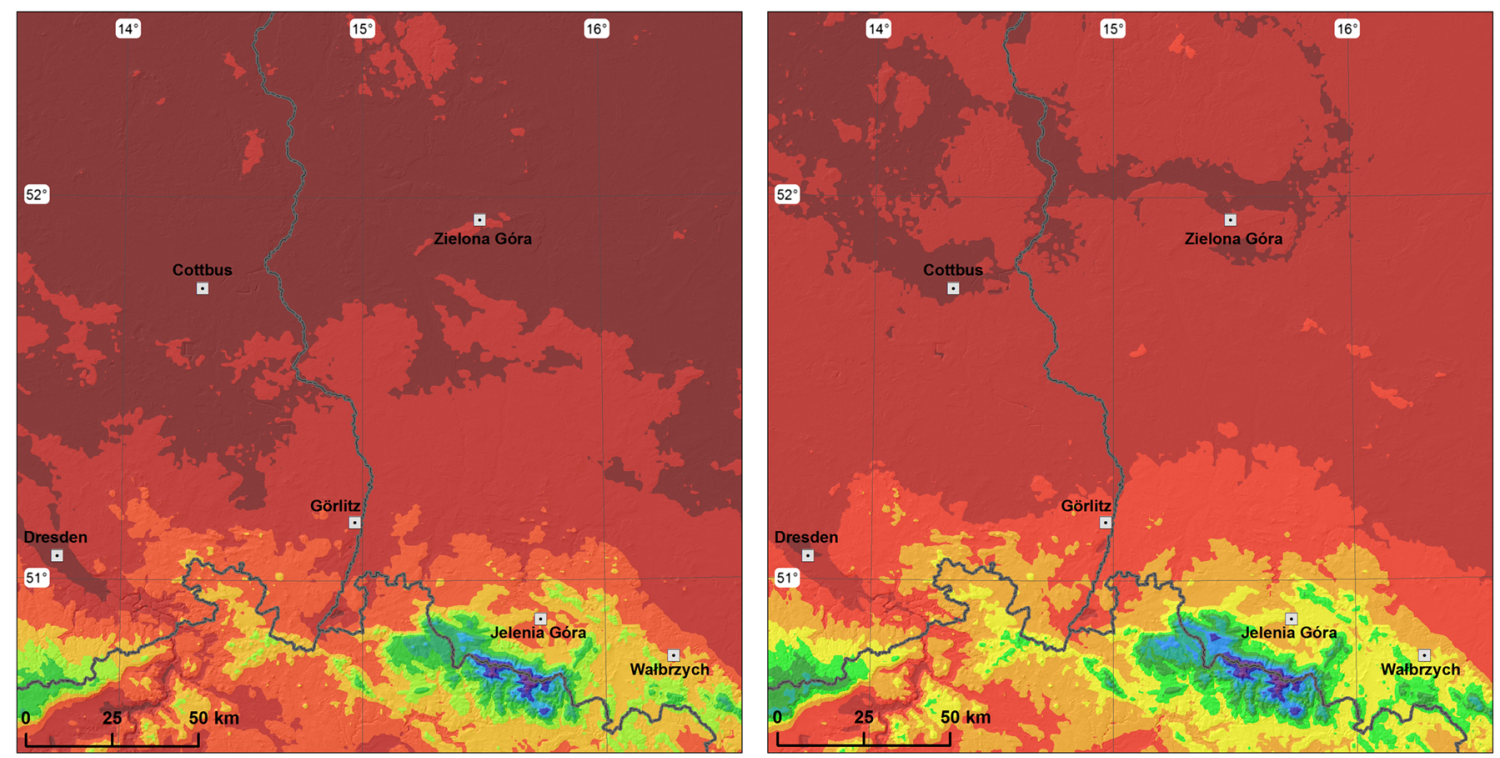

\section{SAT $\left[{ }^{\circ} \mathrm{C}\right]$}

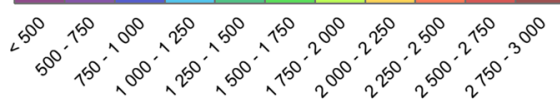

\section{GDD $\left[{ }^{\circ} \mathrm{C}\right]$}

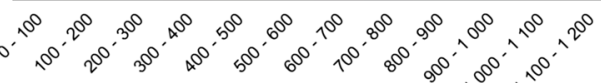
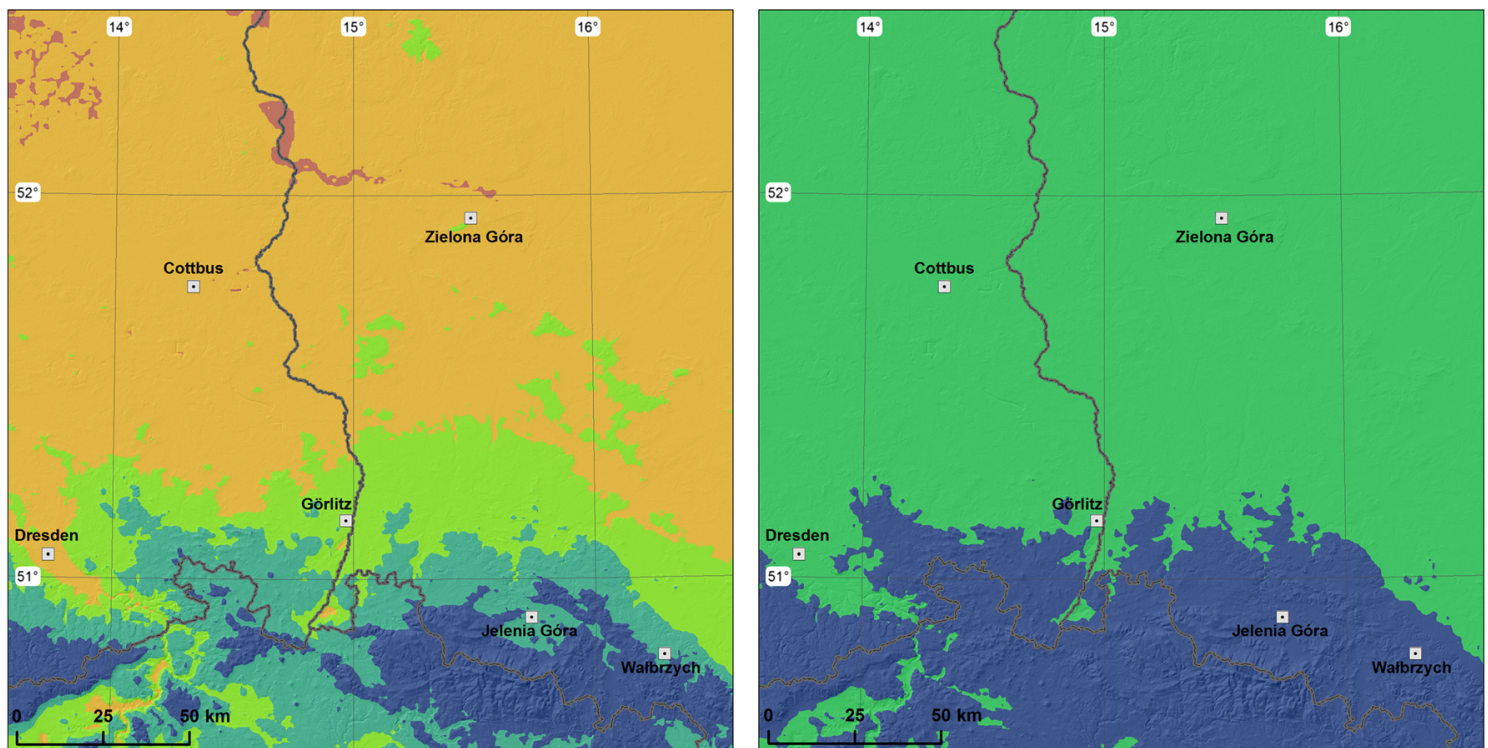

Ripening ability according to SAT:

Suitability classes according to GDD:
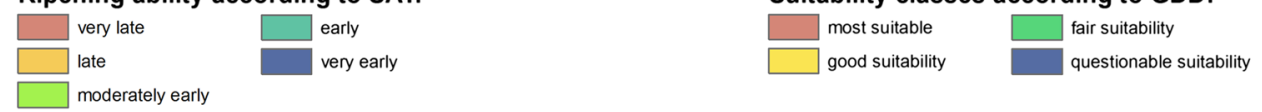

Fig. 4 Average SAT and GDD values and the wine growing suitability classes for the period 1971-2010

- Absolute trend in the SAT and GDD for the period 19712010. This was calculated as follows:

$\operatorname{Tabs}[x, y]=\operatorname{slope}[x, y] *(40-1)$

where $x$ and $y$ are grid cell coordinates, and slope is the slope of simple linear regression for a given grid cell.
- Mann-Kendall S (score) statistic (Mann 1945). A positive (negative) value of $\mathrm{S}$ indicates an upward (downward) trend. Statistical significance of the S statistic was also calculated and marked on the maps of the absolute trend. The Mann-Kendall statistics were calculated with the $\mathrm{R}$ statistical package using the Kendall library. 

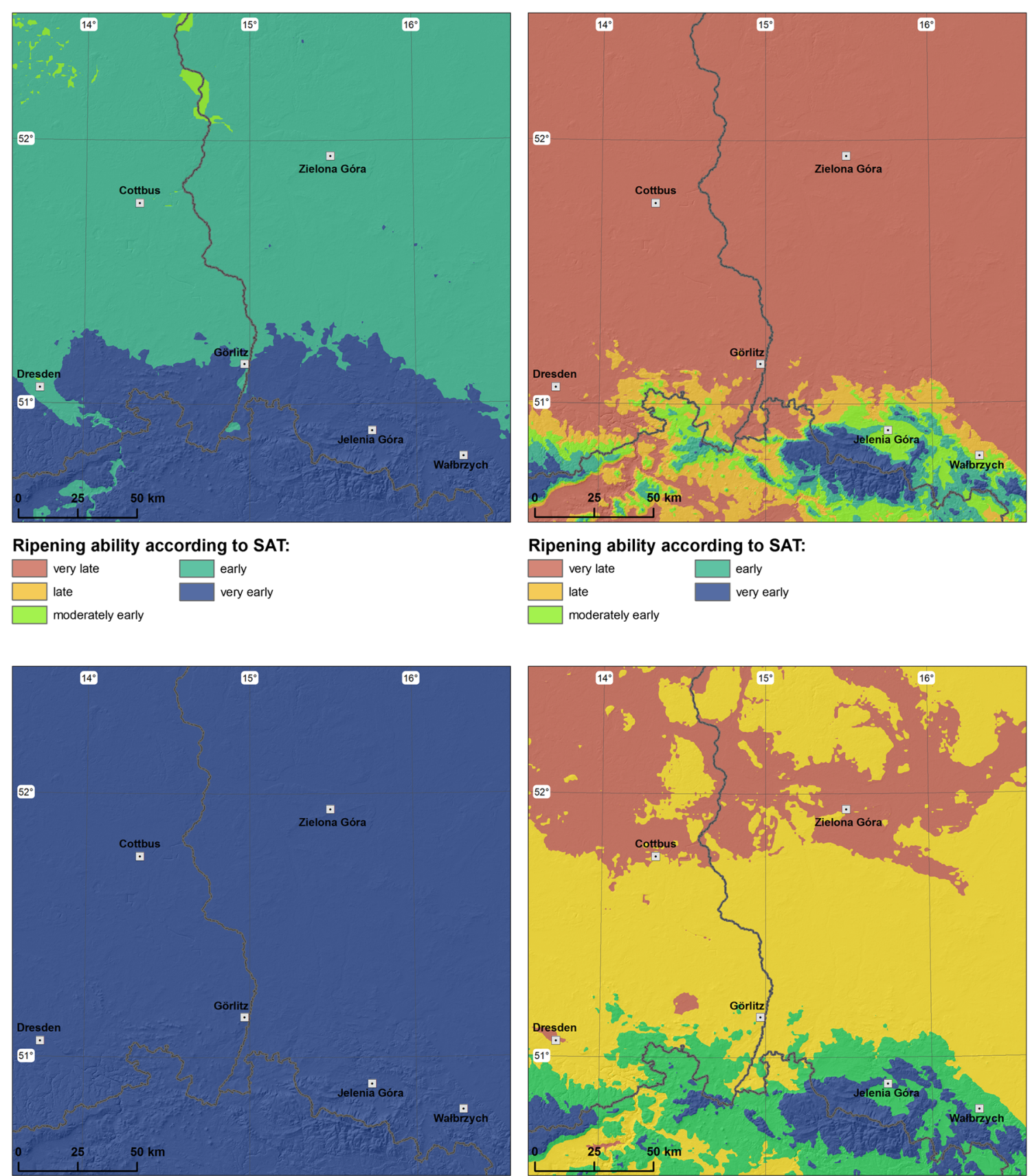

Suitability classes according to GDD:

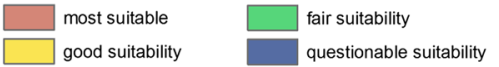

Suitability classes according to GDD:

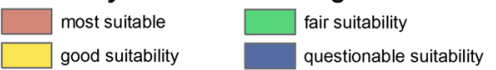

Fig. 5 SAT and GDD classes for the cold year 1980 (left column) and warm year 2006 (right column)

- The number of years with the SAT or GDD below the acceptable threshold value for wine grapes growing. This was done to delineate the areas of relatively large climatological risk for wine grapes cultivation.

- For each grid cell, the number of years within each SAT or GDD class was calculated. Two maps were calculated; the first one shows the SAT or GDD class which was observed for 20 years or more in the 1971-2010 period. For the second map, the 30-year threshold is applied. This shows which class was the most often observed in a given grid.

\subsection{Regional statistics}

For each year, the total acreage in the study region covered by each class, according to the classifications presented in 

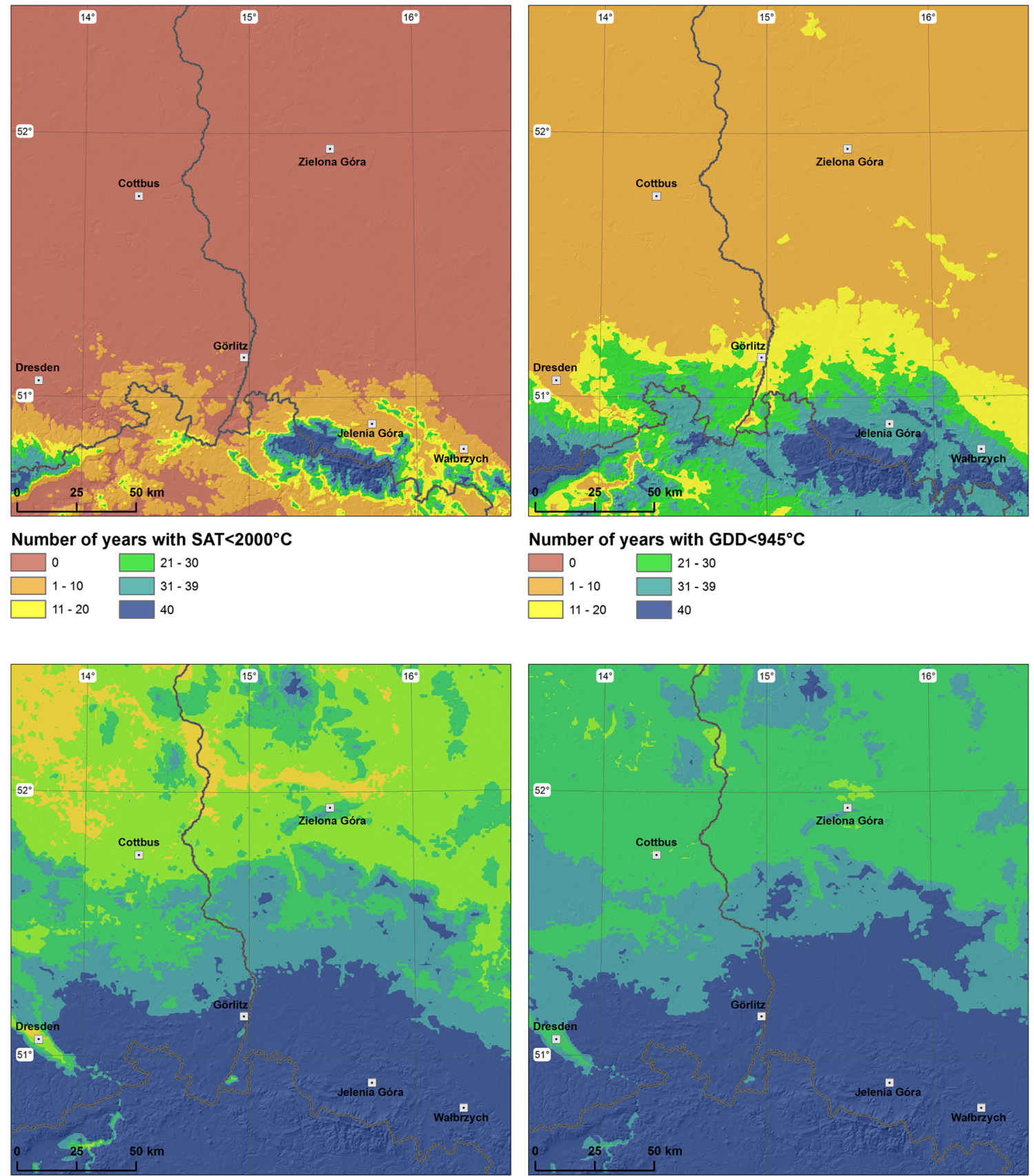

Number of years with SAT $>2900^{\circ} \mathrm{C}$

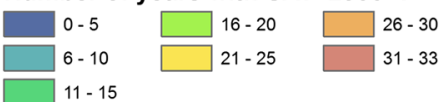

Number of years with $\mathrm{GDD}>1165^{\circ} \mathrm{C}$

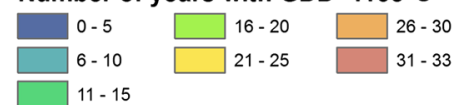

Fig. 6 Number of years not suitable for wine grapes cultivation according to SAT and of questionable suitability according to GDD (top row) and the number of years suitable for very late ripening (SAT) and of good suitability (for GDD) in the 1971-2010 period

Tables 1,2 and 4 , is calculated. With this information, for each class, Mann-Kendall tau statistic is obtained. The tau statistic is a measure of correlation, and therefore, it measures the strength of relationship between the two variables. Tau takes values between \pm 1 , and positive values indicate that the ranks of both variables increase together, whilst a negative correlation indicates that as the rank of one variable increases, the other decreases. Therefore, it describes the temporal changes of the total area for each class, according to SAT, GDD or the joint SAT and GDD classification. Considering the observed increase in air temperatures in the 1971- 

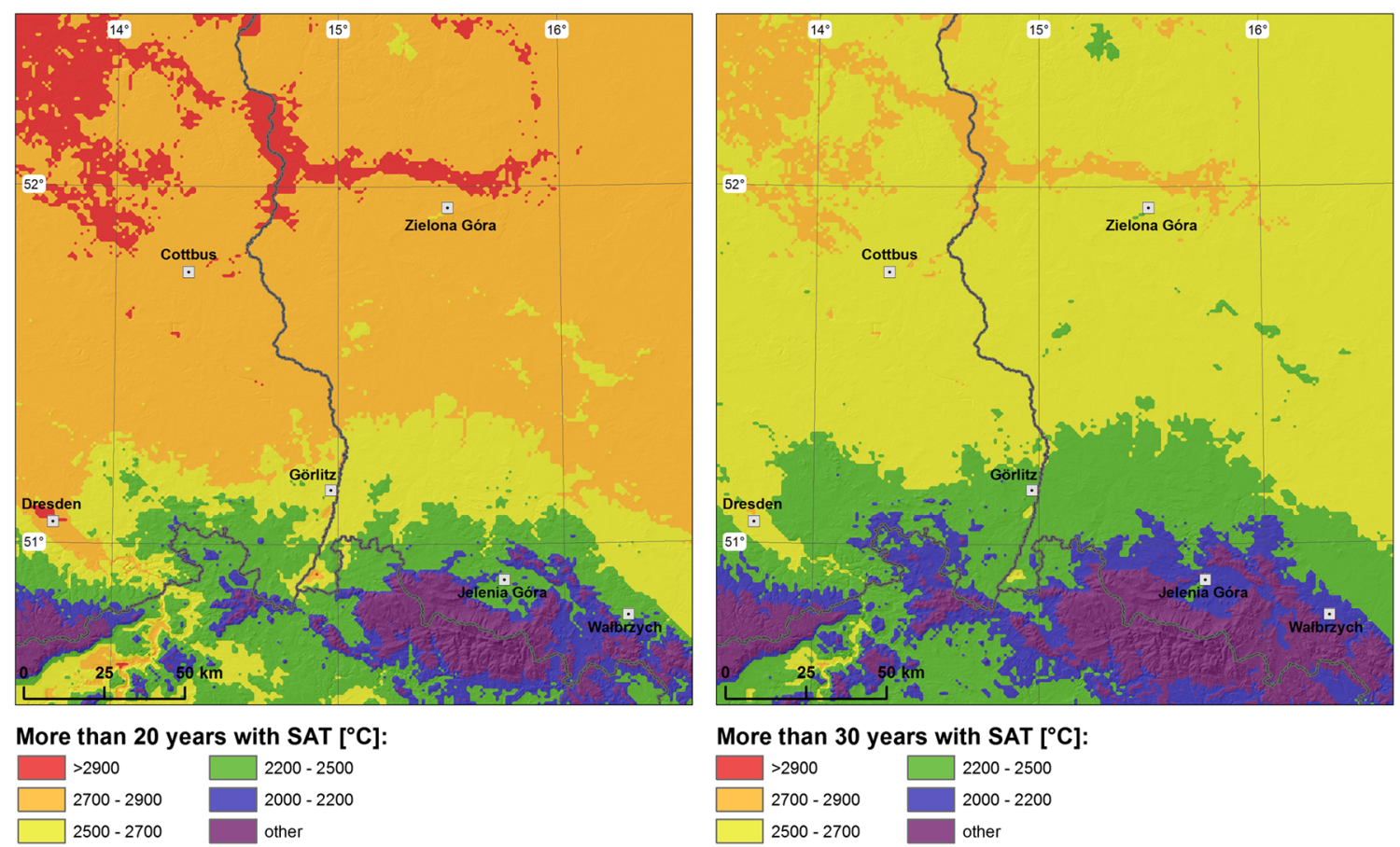

Fig. 7 The most often observed SAT class. Left column - the SAT class observed 20 years or more and right column - the SAT class observed 30 years or more in the 1971-2010 period

2010 period, it is expected that the total area for classes suitable for late-ripening varieties is increasing from 1971 to 2010 (Jones et al. 2005; Moriondo et al. 2011). The statistical significance of these changes is also calculated.

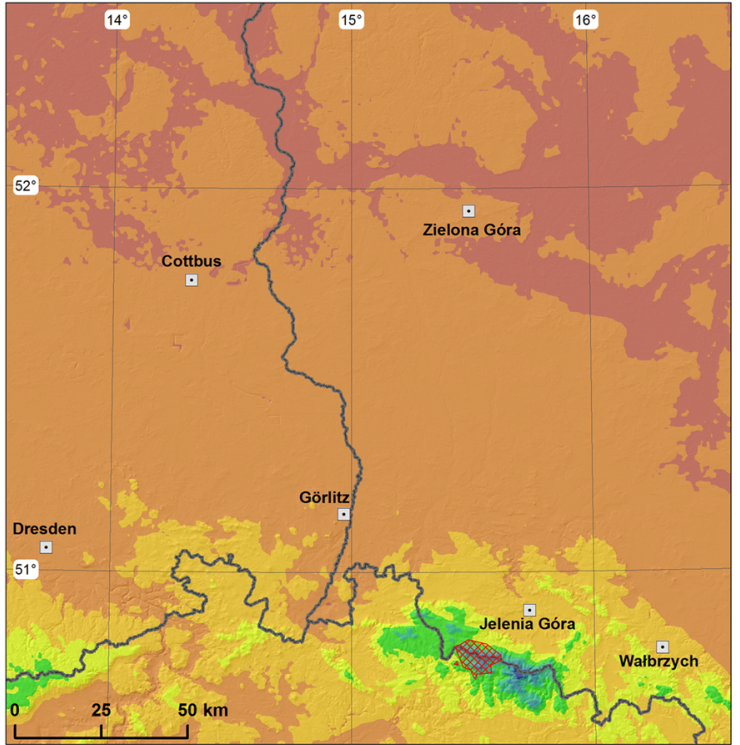

SAT trend $\left[{ }^{\circ} \mathrm{C} / 40\right.$ years]
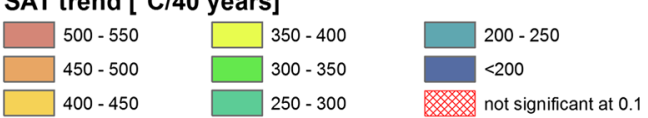

\section{Results}

The results are organized as follows: first, the temporal variability of agroclimatological indices, with SAT as an example, is presented for selected meteorological stations. Second,

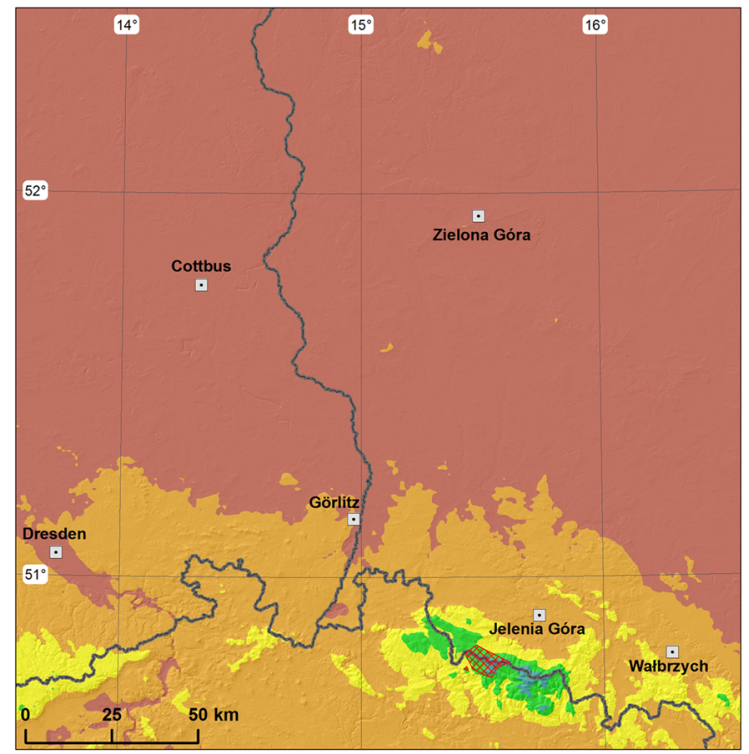

\section{GDD trend $\left[{ }^{\circ} \mathrm{C} / 40\right.$ years]}

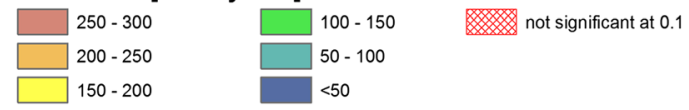

Fig. 8 Absolute trend for SAT and GDD in the 1971-2010 period and its statistical significance 


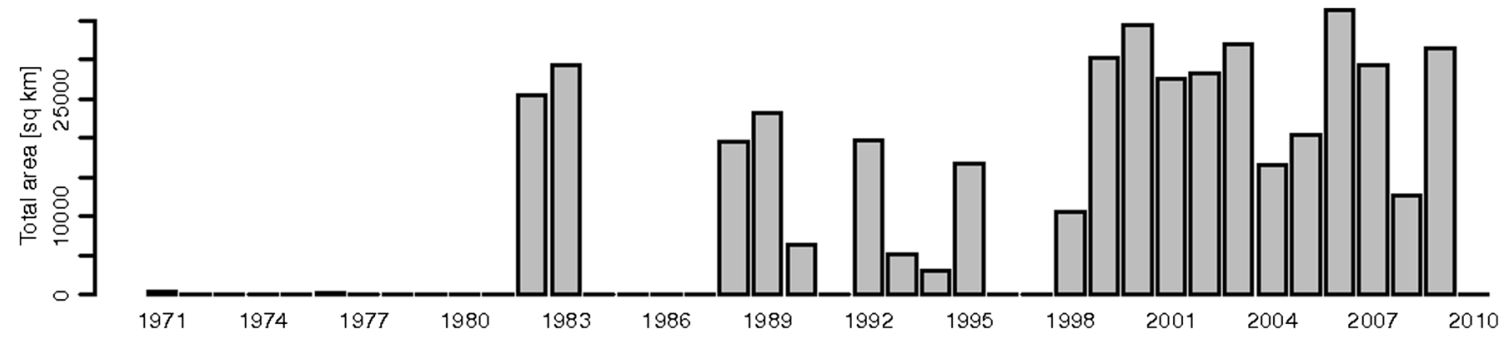

Fig. 9 Total acreage $\left(\mathrm{km}^{2}\right)$ of the SAT class suitable for very late ripening (SAT $>2,900{ }^{\circ} \mathrm{C}$ ) for each year of the 1971-2010 period

spatial patterns of SAT and GDD values and trend in the 1971-2010 period are presented, followed by the results of the extreme years in the analyzed period. Finally, the changes in the total acreage suitable for different varieties of grapes are shown.

The measurement-based temporal variability of SAT for selected stations located at various elevations a.s.l. is given in Fig. 3. The temporal profiles calculated for GDD are very similar (and not presented here). There is a clear and expected decrease in the value of both SAT and GDD with elevation, and the temporal variability is also smaller for higher elevations. Year-to-year changes in SAT and GDD are similar for all presented stations. There are two extreme years: 1980 and 2006. Year 1980 was cold, with low values of SAT and GDD indices. Year 2006 was warm, with peaks in SAT and GDD for all meteorological stations. For selected stations, basic statistics for SAT and GDD are shown in Table 5.

There is a clear, positive and statistically significant temporal trend in SAT and GDD for all five stations presented in Fig. 3. The trend is stronger for the lowland stations and is less pronounced for the higher elevations, especially for the Śnieżka mountain station. There is also large year-to-year variability in both SAT and GDD values, with a good example for years 1990-1993. Both 1990 and 1993 are relatively warm, while a significant drop in SAT and GDD was observed in 1992.

Average spatial distribution of SAT and for the period 1971-2010 is presented in Fig. 4. Similarly to the results for the measurements at the stations, there is a clear relation between the long-term average SAT and GDD, and elevation. The majority of the lowland area in the north of the study area can be classified as suitable for late ripening according to the SAT classification. Entire lowland area represents also class of

Table 6 Trend in total area of the study region suitable for each SAT class

\begin{tabular}{llll}
\hline SAT & Varieties & tau & $\begin{array}{l}\text { Statistical } \\
\text { significance }\end{array}$ \\
\hline $2,000-2,200$ & Very early ripening & -0.428 & 0.000 \\
$2,200-2,500$ & Early ripening & -0.444 & 0.000 \\
$2,500-2,700$ & Moderately early ripening & -0.162 & 0.145 \\
$2,700-2,900$ & Late ripening & 0.092 & 0.413 \\
$>2,900$ & Very late ripening & 0.437 & 0.000 \\
\hline
\end{tabular}

fair suitability according to GDD, if the long-term average values are considered. For SAT, there are some small areas suitable for very late-ripening varieties. Highlands and mountains in the south are climatologically not suitable or of questionable suitability if long-term average SAT and GDD values are concerned.

When the extreme years (1980 - cold year and 2006warm year) are compared with the long-term mean values, large changes in spatial allocation of the given area to the SAT or GDD classes are observed (Fig. 5). If the cold year is considered, the majority of the area is suitable for early- or very-early-ripening varieties of wine grapes according to SAT. There are only minor areas suitable for moderately earlyripening varieties. If more demanding classification of GDD is applied, the entire region is of questionable suitability. For the warm year of 2006, the majority of the study region is suitable for very late-ripening varieties in terms of SAT and is represented by the classes of good to most suitable in terms of SAT.

Considering the large year-to-year variability in SAT and GDD, there is a question of the risk for wine grapes cultivation in the study area. It must be emphasized that there are other factors potentially dangerous for wine grapes cultivation (like spring frosts), and this risk assessment refers to the problems related with insufficient values of SAT and GDD. The risk was described by calculating the number of years above/below the selected SAT and GDD threshold for each grid (Fig. 6). For SAT, $<2,000$ and $>2,900{ }^{\circ} \mathrm{C}$ thresholds were used, as these show the classes not suitable for wine grapes cultivation and suitable for very late ripening, respectively. For GDD, the selected thresholds were $<945$ and $>1,169^{\circ} \mathrm{C}$, which describe the questionable suitability and good to most suitable classes, respectively.

Table 7 Trend in total area of the study region suitable for each GDD class

\begin{tabular}{llll}
\hline GDD & Suitability & tau & $\begin{array}{l}\text { Statistical } \\
\text { significance }\end{array}$ \\
\hline$>1,389$ & Most suitable & 0.233 & 0.082 \\
$1,165-1,389$ & Good suitability & 0.375 & 0.002 \\
$945-1,164$ & Fair suitability & 0.193 & 0.082 \\
$<945$ & Questionable suitability & -0.412 & 0.000 \\
\hline
\end{tabular}


Table 8 Trend in total area of the study region suitable for each SAT and GDD class

\begin{tabular}{lllll}
\hline SAT and GDD & & Profile & tau & Statistical significance \\
\hline$<2,500$ & $<945$ & Not suitable and questionable suitability for very early and early ripening & -0.433 & 0.000 \\
$2,500-2,900$ & $945-1,164$ & Fair suitability for moderately early and late ripening & 0.004 & 0.981 \\
$>2,900$ & $945-1,164$ & Fair suitability for very late ripening & 0.325 & 0.005 \\
$>2,900$ & $>1,164$ & Good suitability for very late ripening & 0.429 & 0.000 \\
\hline
\end{tabular}

The entire lowland areas were not at risk if the very-earlyripening varieties are considered according to the SAT classification (Fig. 6), as the threshold value $<2,000$ was not exceeded in the 1971-2010 period. However, if GDD is considered, there are several years in this period below the threshold $<945$, also for the lowland areas. This means that the production of grapes might be at risk. The risk of the more demanding varieties, described with the number of years with the SAT $>2,900$ and GDD $>1,169^{\circ} \mathrm{C}$, is much higher. For the majority of the study area, the number of years not exceeding these thresholds is above 20 .

The maps in Fig. 7, showing for each SAT class the areas with more than 20 or 30 years in the 1971-2010 period, can be understood as the "risk" maps for cultivation of vine varieties according to their ripening abilities. The threshold of $50 \%$ (20 years) expresses the overall "moderate risk" and the threshold of $75 \%$ (30 years) the "low risk" for cultivation of varieties dedicated for specific heat accumulation conditions. For the majority of the study area, the SAT class suitable for late ripening was observed for over $50 \%$ of years of the $1971-$ 2010 period (Fig. 7). If the $75 \%$ year threshold is applied, moderately late ripening is the dominant class according to SAT. The class suitable for very late ripening appears in the NW part of the study area and only if the $50 \%$ year threshold is applied. Similar pattern is observed for GDD (not shown here).

The "risk maps" presented above refer to overall conditions observed in a 40-year period and do not account for observed climate change that significantly minimizes the risk with the increasing heat load amount (Fig. 3). There is a strong and positive temporal trend in SAT and GDD values observed in the study area (Fig. 8). For the majority of the lowland area, the increase in SAT exceeds $450{ }^{\circ} \mathrm{C}$ in the $1971-2010$ period. The increase of GDD is also noticeable and exceeds $20 \%$ of the 1971-2010 mean value (Fig. 4). There is a clear negative correlation between the absolute trend value and elevation. The increase in SAT and GDD is the smallest in the mountainous part of the region. For the majority of the study area, the trend is statistically significant, with the $p$ value $<0.1$.

The statistically significant trend in SAT and GDD values, observed in the 1971-2010 period, suggests that there will be also a trend in the total acreage for each SAT, GDD and SAT/ GDD suitability classes. The total acreage for each class was calculated for each year, based on the gridded SAT and GDD information, and the Man-Kendall tau statistics were used to describe these tendencies. As expected based on the changes observed in SAT and GDD values, the total acreage for the classes suitable for early and very early ripening, according to the SAT classification, is decreasing. The change is statistically significant, with the $p$ value $\ll 0.1$. On the other hand, the area covered by the classes suitable for late and very late ripening is increasing. The increase in frequency of years for which the class suitable for very late ripening is very large (Fig. 9). The areas covered with this class are observed each year after 1998 and were sparse before 1988. The trend is statistically significant for the very late-ripening grapes. Similar tendencies are observed regardless to the classification applied (Tables 6, 7 and 8).

\section{Summary and conclusions}

In our study, we show how the values of SAT and GDD indices, describing the heat accumulation important for wine grapes growing, have changed over the 1971-2010 period in the transboundary region of Poland, Germany and Czech Republic. The changes are very significant, and the climate of this area shifts towards more optimal, in terms of accumulative heat indexes, for cultivation of more demanding varieties of grapes. The main findings are as follows:

- There are positive trends in SAT and GDD values, statistically significant for the majority of the study region.

- The trends in SAT and GDD are not spatially homogenous, and they decrease with elevation.

- The observed trends in SAT and GDD make the transboundary area of Poland and Germany suitable for cultivation of wine grapes, even for the varieties which are demanding in terms of accumulated heat.

- The observed climate change in the region reduces the risk for wine grapes cultivation.

- There is also a statistically significant trend in the total acreage suitable for wine grapes cultivation. The area suitable for less demanding varieties is decreasing. The opposite is observed for more demanding crops.

The results presented in this work support earlier findings reported, e.g. by Jones et al. (2005) and Moriondo et al. 
(2011). This relatively far-north located area has become suitable for wine grape cultivation, even for more demanding varieties in terms of accumulated heat. Further studies could better assess the potential impact of future climate change on wine grape cultivation in this region. Climatologically, concerning the accumulated characteristics of SAT and GDD, the region is now suitable for cultivation of moderately early- or late-ripening varieties of grapes according to SAT. If the observed increasing trend in SAT and GDD continues in the future, the cultivation of very late-ripening varieties will also be possible.

Acknowledgements The authors would like to thank two anonymous rewievers for their comments. This work was funded within the EFRR SN-PL KLAPS project.

Open Access This article is distributed under the terms of the Creative Commons Attribution License which permits any use, distribution, and reproduction in any medium, provided the original author(s) and the source are credited.

\section{References}

Amerine MA, Winkler AT (1944) Composition and quality of musts and wines of California grapes. Hilgardia 15:493-673

Arnold CY (1960) Maximum-minimum temperatures as a basis for computing heat unit. Proc Am Soc Horticultural Sci 76:682-692

Bock A, Sparks T, Estrella N, Menzel A (2011) Changes in the phenology and composition of wine from Franconia, Germany. Clim Res 50: $69-81$

Bonhomme R (2000) Bases and limits to using 'degree.day' units. Eur J Agron 13:1-10

de Orduna RM (2010) Climate change associated effects on grape and wine quality and production. Food Res Int 43:1844-1855

Duchene E, Huard F, Dumas V, Schneider C, Merdinoglu D (2010) The challenge of adapting grapevine varieties to climate change. Clim Res 41:193-204

Gilmore EC, Rogers JS (1958) Heat units as a method of measuring maturity in corn. Agron J 50:611-615

Jones GV, Davis RE (2000) Climate influences on grapevine phenology, grape composition, and wine production and quality for Bordeaux, France. Am J Enol Viticult 51:249-261

Jones PD, Moberg A (2003) Hemispheric and large-scale surface air temperature variations: an extensive revision and an update to 2001. J Clim 16:206-223

Jones GV, White MA, Cooper OR, Storchmann K (2005) Climate change and global wine quality. Clim Chang 73:319-343

Kjellstrom E (2004) Recent and future signatures of climate change in Europe. Ambio 33:193-198

Kożuchowski K, Degirmendžić J (2005) Contemporary changes of climate in Poland: trends and variation in thermal and solar conditions related to plant vegetation. Pol J Ecol 53:283-297

Lisek J (2008) Climatic factors affecting development and yielding of grapevine in central Poland. J Fruit Ornam Plant Res 286:285-293
Lobell DB, Cahill KN, Field CB (2007) Historical effects of temperature and precipitation on California crop yields. Clim Chang 81:187-203

Lobell DB, Burke MB, Tebaldi C, Mastrandrea MD, Falcon WP, Naylor RL (2008) Prioritizing climate change adaptation needs for food security in 2030. Science 319:607-610

Mann HB (1945) Nonparametric tests against trend. Econometrica 13: 245-259

McMaster GS, Wilhelm WW (1997) Growing degree-days: one equation, two interpretations. Agr Forest Meteorol 87:291-300

Moriondo M, Bindi M, Fagarazzi C, Ferrise R, Trombi G (2011) Framework for high-resolution climate change impact assessment on grapevines at a regional scale. Reg Environ Change 11:553-567

Myśliwiec R (2003) Uprawa winorośli. Państwowe Wydawnictwa Rolnicze i Leśne (in Polish)

Olesen JE, Bindi M (2002) Consequences of climate change for European agricultural productivity, land use and policy. Eur J Agron 16:239-262

Pruess KP (1983) Day-degree methods for pest-management. Environ Entomol 12:613-619

Szymanowski M, Kryza M (2012) Local regression models for spatial interpolation of urban heat island-an example from Wrocaw, SW Poland. Theor Appl Climatol 108:53-71

Szymanowski M, Kryza M, Smaza M (2010) A GIS approach to spatialize selected climatological parameters for wine-growing in Lower Silesia, Poland. Proceedings of the Bioclimatology and natural hazards conference. Polana nad Detvou, Slovakia

Szymanowski M, Kryza M, Spallek W (2012) Air temperature atlas for Poland: the methodical approach. Rozprawy Naukowe Instytutu Geografii i Rozwoju Regionalnego Uniwersytetu Wrocławskiego (in Polish)

Szymanowski M, Kryza M, Spallek W (2013) Regression-based air temperature spatial prediction models: an example from Poland. Meteorol Z. doi:10.1127/0941-2948/2013/0440

Tobler W (1970) A computer movie simulating urban growth in the Detroit region. Econ Geogr 46:234-240

Trenberth KE, Jones PD, Ambenje P, Bojariu R, Easterling D, Klein Tank A, Parker D, Rahimzadeh F, Renwick JA, Rusticucci M, Soden B, Zhai P (2007) Observations: surface and atmospheric climate change. The physical science basis, Contribution of Working Group I to the Fourth Assessment Report of the Intergovernmental Panel on Climate Change. In: Solomon S, Qin D, Manning M, Chen Z, Marquis M, Averyt KB, Tignor M, Miller HL (eds) 987 pp

Wang JY (1960) A critique of the heat unit approach to plant-response studies. Ecology 41:785-790

Webb LB, Whetton PH, Barlow EWR (2011) Observed trends in winegrape maturity in Australia. Glob Change Biol 17:2707-2719

Webb LB, Whetton PH, Bhend J, Darbyshire R, Briggs PR, Barlow EWR (2012) Earlier wine-grape ripening driven by climatic warming and drying and management practices. Nature 2: 259-264

White MA, Diffenbaugh NS, Jones GV, Pal JS, Giorgi F (2006) Extreme heat reduces and shifts United States premium wine production in the 21st century. Proc Natl Acad Sci U S A 103: $11217-11222$

WMO (2013) The global climate 2001-2010: a decade of climate extremes. Summary report, Geneva, WMO-No. 1119

Yang SS, Logan J, Coffey DL (1995) Mathematical formulas for calculating the base temperature for growing degree-days. Agr Forest Meteorol 74:61-74 